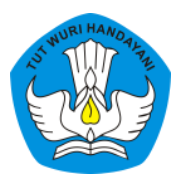

Page: $371-408$

\title{
PENGEMBANGAN DESAIN ALGORITMA HITUNG DASAR BERBANTUAN PROGRAM MICROSOFT EXCEL
}

\author{
Sawir \\ UPTD Sekolah Dasar Negeri 1 Tanjungkerta, Indonesia \\ Email: sawir242@gmail.com
}

Published: Jul 30, 2020

Article Url: https://ojsdikdas.kemdikbud.go.id/index.php/didaktika/article/view/131

\begin{abstract}
The study was conducted to determine the empowerment of media design algorithm for addition, subtraction, multiplication, and distribution ( porogapit) basic calculation of how to briefly assisted by Microsoft Excel program on the motivation and learning outcomes of 24 grade IV students of SD Negeri 1 Tanjungkerta in the academic year 2018 / 2019. The research phase included: media identification, instrument simulation, media observation, product revisions, product presentations and publications. Research data collection through the process of observation, observation, and knowledge tests. Analysis of research data is carried out quantitatively and qualitative descriptions are the basis of the research conclusions. The achievement level of students' learning motivation was $88 \%$ strongly agreed, $12 \%$ agreed, and the mean participation was $94.17 \%$. Activities of successful student performance during the learning process reached $89.33 \%$. Initial research there were $25 \%$ able to use the basic arithmetic algorithm for solving problems in mathematical problems. Through the final knowledge test the research achieved learning success with the predicate of enough 11 students, both 7 students, and very good 3 students. Class completeness for the final knowledge competence reached $87.50 \%$. It was concluded from the research carried out, that the application of the design media algorithm of addition, subtraction, multiplication, and division ( porogapit) short way assisted by Microsoft Excel program is considered effective as a medium of learning mathematics.
\end{abstract}

Keywords: Design, Algorithms, Basic Calculations, Microsoft Excel. 


\begin{abstract}
Abstrak
Penelitian dilaksanakan untuk mengetahui keberdayaan media desain algoritma penjumlahan, pengurangan, perkalian, dan pembagian ( porogapit) hitung dasar cara singkat berbantuan program microsoft excel terhadap motivasi dan hasil belajar 24 siswa kelas IV SD Negeri 1 Tanjungkerta tahun pelajaran 2018/2019. Tahap penelitian meliputi: identifikasi media, simulasi instrumen, observasi media, revisi produk, presentasi, dan publikasi produk. Pengumpulan data penelitian melalui proses observasi, pengamatan, serta tes pengetahuan. Analisis data penelitian dilaksanakan secara kuantitatif dan deskripsi kualitatif sebagai dasar simpulan penelitian. Capaian tingkat motivasi belajar siswa 88\% sangat setuju, 12\% setuju, dan rerata partisipasi 94,17\%. Aktivitas keberhasilan kinerja siswa selama proses pembelajaran mencapai 89,33 \%. Awal penelitian terdapat 25\% mampu memanfaatkan algoritma hitung dasar untuk penyelesaian masalah dalam soal-soal matematika. Melalui tes pengetahuan akhir penelitian dicapai keberhasilan belajar dengan predikat cukup 11 siswa, baik 7 siswa, dan amat baik 3 siswa. Ketuntasan kelas untuk kompetensi pengetahuan akhir penelitian tercapai 87,50\%. Disimpulkan terhadap penelitian yang dilaksanakan, bahwa penerapan media desain algoritma penjumlahan, pengurangan, perkalian, dan pembagian ( porogapit ) cara singkat berbantuan program Microsoft Excel dianggap efektif sebagai media pembelajaran matematika.
\end{abstract}

Keywords: Desain, Algoritma, Hitung Dasar, Microsoft Excel.

\title{
A. Pendahuluan
}

Terampil berhitung menjadi kemampuan utama dan harus dikuasai siswa pembelajar untuk siap mengikuti proses pembelajaran matematika secara berkelanjutan. Ketika aktivitas pembelajaran matematika, siswa akan menerapkan kemampuan prosedural algoritma hitung penjumlahan, pengurangan, perkalian, maupun pembagian sebagai keterampilan algoritma dasar pembelajaran matematika. Siswa Sekolah Dasar (SD) sangat membutuhkan ketuntasan penguasaan prosedural operasi hitung dasar secara optimal. Siswa yang telah lulus dari jenjang pendidikan SD tidak akan merasa kesulitan untuk mengikuti proses pembelajaran matematika yang sangat membutuhkan kemampuan penerapan terampil prosedural (algoritma) hitung penjumlahan, pengurangan, perkalian, dan pembagian (porogapit). 
Pengalaman belajar matematika yang bermakna ketika di SD akan menjadi dasar ketika mengikuti kegiatan belajar matematika pada jenjang sekolah selanjutnya. Jika ketika di SD mendapatkan banyak pengalaman belajar matematika yang bermakna maka ketika di SMP, SMA, ataupun SMK tidak akan menghadapi masalah yang tidak sepantasnya muncul bukan pada saatnya. Terkait dengan kemampuan prosedural (algoritmik) operasi hitung dasar matematika, maka ketika berada di SD semestinya telah dikuasai dengan baik dan benar bagaimana terampil menerapkan proses algoritma hitung dasar matematika.

Pada tahap awal pemahaman fakta, konsep, dan prosedural ( algoritmik) berhitung pembelajaran matematika dengan bilangan-bilangan yang kecil di SD kelas awal dianjurkan melibatkan peragaan-peragaan benda konkret. Sedangkan untuk kelas tinggi di SD secara bertahap proses pembelajaran diarahkan melalui pemahaman dengan melibatkan model konkret ke model yang abstrak. Proses pemahaman model konkret secara bertahap beralih ke model abstrak dilakukan untuk mengakomodir kebutuhan pengalaman edukatif yang bermakna sesuai perkembangan kognitif yang bergerak dari kemampuan pemahaman konkret menuju pada suatu kemampuan proses pemahaman prosedural secara abstrak.

Ketika siswa mengikuti proses pembelajaran untuk menyelesaikan masalah pada soal-soal latihan matematika sangat membutuhkan kompetensi berpikir dengan penekanan keterampilan prosedural (algoritmik) berhitung yang semakin menuntut kemampuan berpikir secara abstrak. Pembelajaran akan sangat bermakna jika dalam prosesnya melibatkan media perangkat TIK sebagai media komunikasi proses pembelajaran. Hal ini dilakukan untuk menguatkan perolehan pengalaman edukatif yang bermakna dan sejalan dengan pandangan 
yang dijelaskan oleh Tualeka., Z. dkk. (2007: 21), bahwa terkadang soalsoal yang melibatkan perhitungan matematis dapat dilakukan secara manual atau cukup menggunakan kemampuan otak kita atau bisa juga dihitung sederhana. Jika soal-soal tersebut dirasa cukup sulit, biasanya kita menggunakan alat bantu menghitung yang disebut kalkulator.

Proses pendidikan dianggap efektif jika mampu menghasilkan peserta didik yang siap menghadapi persaingan kehidupan secara lokal, nasional, maupun global. Tuntutan kebutuhan kehidupan abad-21 berubah sangat komplek dan cepat. Kehidupan di era revolusi industri 4.0 akan membutuhkan penguasaan kecakapan hidup yang sangat mendesak untuk dapat dikuasai sedini mungkin terutama terkait dengan kecakapan digital sebagai indikator kecakapan di era milenial. Dengan demikian sangatlah sesuai jika dalam proses pembelajaran untuk jenjang SD sedini mungkin diperkenalkan suatu aktivitas pembelajaran yang dapat diharapkan mampu memberikan makna pengalaman pembelajaran edukatif. Pengalaman edukatif termaksud diperoleh siswa ketika proses pembelajaran dengan menerapkan perangkat teknologi informasi dan komunikasi secara nyata. Lebih jauh ditegaskan oleh Tualeka., Z. dkk. (2007: 30), bahwa pada saat ini kehadiran media komputer program microsoft excel sebagai media digital yang utama untuk memudahkan pekerjaan seseorang beraktivitas mengolah angka dengan operasi hitung tertentu.

Penggunaan sarana atau media hitung untuk mengolah angkaangka ketika kegiatan pembelajaran memang dibutuhkan dengan tujuan untuk meringankan tingkat kesulitan siswa ketika berupaya memperoleh suatu pengalaman belajar yang bermakna. Kehadiran perangkat teknologi komputer merupakan sarana atau media komunikasi untuk menguatkan 
perolehan pengalaman edukatif bagi siswa, memperkecil munculnya kejenuhan belajar, membangkitkan motivasi, menumbuhkan rasa keingintahuan siswa terhadap pembelajaran matematika, suasana belajar menyenangkan, bahkan diharapkan mampu memfasitasi media komunikasi proses berpikir siswa dalam bentuk visualisasi ilustrasi model abstrak untuk suatu proses algoritma kompetensi keterampilan belajar matematika.

Kegiatan pembelajaran matematika yang disajikan guru masih belum secara maksimal memfokuskan proses perolehan pengalaman belajar yang bermakna. Pembelajaran matematika di SD Negeri 1 Tanjungkerta khususnya masih berfokus pada hasil akhir tingkat penguasaan konten materi pembelajaran matematika. Perolehan pengalaman belajar yang didapat ketika proses pembelajaran dilaksanakan masih terabaikan. Ketika proses pembelajaran berlangsung sangat dibutuhkan adanya suatu media pembelajaran yang mampu membawa konten materi atau konsep materi yang akan dipelajari. Hanya dengan media pembelajaran yang mampu mengarahkan alur proses berpikir siswa, suatu tujuan pembelajaran akan dapat tercapai dengan hasil yang optimal.

Kegiatan belajar masih terlihat sangat sederhana, hanya dengan alat belajar papan tulis, kapur tulis, buku paket matematika, buku tulis, bolpoint atau pensil guru mengadakan proses belajar bersama siswa dalam kelas belajar. Metode belajar didominasi ceramah dengan sedikit tanya jawab secara klasikal dilengkapi latihan soal-soal secara mandiri diakhiri dengan kegiatan klasikal pemeriksaan hasil latihan soal-soal. Bahkan yang sangat menghawatirkan terhadap perolehan makna pengalaman belajar, proses belajar dengan model yang menghendaki 
proses berpikir abstrak tanpa melibatkan kehadiran prasarana atau media komunikasi proses belajar. Kejadian seperti digambarkan diawal akan membuat siswa merasa jenuh serta enggan untuk mengikuti pembelajaran, sehingga pada suatu ketika siswa akan merasakan adanya kesulitan mengikuti proses pembelajaran, bahkan berakibat mjunculnya rasa putus asa, prustrasi untuk dapat belajar matematika dengan baik dan benar.

Dari situasi belajar yang dapat dianggap kurang bermakna sebagaimana dijelaskan diatas pada akhirnya akan berdampak didapatnya hasil akhir belajar yang sangat rendah yang ditandai adanya perolehan nilai yang terpaut jauh di bawah nilai standar yang direncanakan dan ditetapkan pihak sekolah. Pelaksanaan pembelajaran yang disajikan guru masih belum menyesuaikan dengan kebutuhan kondisi psikhologis sesuai karakter yang ada pada diri siswa. Kenyataan akhir yang dialami oleh kebanyakan siswa SD Negeri 1 Tanjungkerta adalah rendahnya tingkat penguasaan kemampuan proses serta hasil belajar matematika.

Bidang keilmuan matematika merupakan bidang keilmuan yang abstrak serta bersifat deduktif. Untuk dapat mengikuti proses pembelajaran matematika dengan baik bagi siswa pada jenjang SD tidak akan dapat langsung menyimak penyajian bentuk-bentuk model abstrak. Penguasaan konsep abstrak diawali dengan proses pemahaman yang disimak melalui model-model konkret dan bertahap beralih pada ilustrasi-ilustrasi yang mengarahkan pemahaman siswa melalui model abstrak.

Konsep penjumlahan, pengurangan, perkalian, dan pembagian (porogapit) merupakan konsep yang abstrak yang harus dipahami secara baik serta terampil dalam penerapanya untuk penyelesaian beragam masalah matematika. Algoritma hitung dasar matematika adalah merupakan suatu model prosedural yang abstrak yang harus tuntas dikuasai hingga tingkat 
penerapanya. Model algoritma penjumlahan bersusun singkat, algoritma pengurangan bersusun singkat, algoritma perkalian bersusun singkat, dan algoritma pembagian bersusun singkat adalah merupakan model algoritma hitung dasar matematika yang mutlak dikuasai siswa semenjak jenjang SD. Untuk konten bilangan dengan nilai-nilai kecil masih dimungkinkan diperagakan pemahamanya melalui model-model konkret, akan tetapi untuk konten bilangan-bilangan dengan nilai yang besar akan mengalami kesulitan jika harus diperagakan melalui model-model konkret. Untuk mengarahkan proses berpikir siswa pada pemahaman suatu model prosedural yang sangat mendasar dianggap sangat penting untuk mengahadirkan media komunikasi pembelajaran yang diharapkan dapat diterima oleh kondisi psikhis siswa dengan segala keunikan karakteristiknya. Media Teknologi Informasi dan Komunikasi (TIK) akan mampu menjawab kebutuhan mediasi komunikasi yang menggairahkan semangat siswa untuk belajar bahkan mengilustrasikan model-model prosedural (algoritma) pada kompetensi dasar yang disyaratkan sesuai kurikulum yang ditetapkan. Program Microsoft Excel adalah merupakan suatu program yang memang dirancang dominan untuk mengolah angka yang merupakan konten utama pembelajaran matematika.

Media komunikasi TIK berbasis komputer dengan program Microsoft Excel dimungkinkan untuk dikembangkan manfaat penerapanya sebagai media komunikasi pembelajaran matematika dengan keunikan karakteritik kompetensi dasar yang disyaratkan. Bahkan dengan media program Microsoft Excel motivasi siswa SD sesuai perkembangan karakter individu untuk belajar matematika akan dapat ditumbuhkan. Siswa akan merasakan adanya pembelajaran yang menyenangkan tidak terasa bosan dengan aktivitas belajar yang konvensional bahkan terasa bermakna setelah selesai mengikuti proses pembelajaran. Secara psikhologis siswa akan merasakan adanya kebutuhan untuk belajar berkelanjutan dari materi yang dinggap 
mudah hingga yang sukar dipelajari, dari materi yang sederhana hingga materi yang dianggap kompleks.

Mutu hasil akhir pembelajaran matematika yang baik akan didapat dari serangkaian proses pembelajaran yang bermutu baik pula. Proses pembelajaran yang baik membutuhkan adanya beberapa aspek pendukung yang benar-benar harus ada dan bermakna. Aspek pendukung kelancaran proses pembelajaran yang harus ada diantaranya adalah media komunikasi pembelajaran yang diterapkan dapat diterima oleh kondisi psikhologis serta karakter individu siswa sebagai warga pembelajar serta mampu memberikan makna edukaif dalam arti sesuai dengan kompetensi dasar yang ditetapkan. Tujuan penelitian pengembangan media desain algoritma hitung dasar cara singkat berbantuan program Microsoft Excel, mengetahui pengaruh penerapan media desain algoritma penjumlahan, pengurangan, perkalian, dan pembagian ( porogapit) cara singkat berbantuan media program microsoft excel terhadap proses pembelajaran matematika dan mengetahui pengaruh penerapan media desain algoritma penjumlahan, pengurangan, perkalian, dan pembagian ( porogapit) cara singkat berbantuan program microsoft excel terhadap peningkatan keterampilan untuk penyelesaian masalah dalam soalsoal matematika.

Segala bentuk upaya kreativitas inovasi terhadap kegiatan pendidikan dan pembelajaran yang dilaksakan di lingkungan sekolah akan berpusat pada kebutuhan siswa sebagai pembelajar yang berkelanjutan. Sehingga pemanfaatan media desain algoritma hitung dasar matematika program Microsoft Excel sangat bermanfaat bagi siswa kelas IV SD Negeri 1 Tanjungkerta tahun pelajaran 2018/ 2019. Terjadi peningkatan keterampilan algoritma penjumlahan, pengurangan, perkalian, dan pembagian (porogapit) cara singkat sebagai model abstrak yang dapat diimplementasikan untuk menyelesaikan masalah dalam soal-soal matematika. 


\section{Sawir}

Sebagaimana sudah menjadi kebutuhan bahwa kecakapan penerapan media TIK merupakan kecakapan yang sangat aplikatif untuk suatu aktivitas di era digital milenial dalam kehidupan dunia global. Degan memberdayakan media desain algoritma hitung dasar cara singkat berbantuan program microsoft excel terhadap kegiatan pembelajaran maka pembelajaran akan bermakna sebagai pembelajaran era digital milenial. Ada manfaat inflisit terintegrasi ketika suatu kreasi inovasi desain algoritmik penjumlahan, pengurangan, perkalian, dan pembagian ( porogapit ) cara singkat terdesain dengan berbantuan media komunikasi komputer program microsof excel. Siswa secara nyata dilibatkan pada suatu aktivitas pembelajaran yang bermakna yaitu bagaimana memberdayakan media komputer program microsoft excel untuk suatu kegiatan pembelajaran era digital milenial yang menumbuhkembangkan sikap kritis, kreatif, komunikatif, dan kolaboratif sebagai tuntutan kebutuhan kecakapan hidup Abad 21.

\section{B. Ide Dasar Karya Inovasi}

Kegiatan pembelajaran merupakan aktivitas kegiatan pembelajaran yang pada hakikatnya merupakan kegiatan siswa belajar untuk memperoleh suatu pengalaman edukatif bermakna. Guru pada suatu kegiatan pembelajaran merupakan fasilitator serta motivator bahkan katalisator proses belajar bagi siswa pembelajar. Konten materi pembelajaran merupakan bahan ajar yang harus dapat tersampaikan oleh guru terhadap siswa secara utuh bahkan terserap secara optimal oleh siswa. Untuk suatu proses pembelajaran yang efesien dan efektif jika tersedia suatu media komunikasi pembelajaran yang dapat diterima oleh siswa sesuai dengan keunikan karakter yang dimiliki. 
Ketika siswa mengikuti suatu proses pembelajaran membutuhkan adanya suatu media yang merupakan alat bantu aktivitas menyimak, menyerap materi pembelajaran yang disampaikan oleh guru. Segala bentuk informasi dari guru atau dari sumber lainya membutuhkan media komunikasi yang efektif sehingga proses transfer informasi yang berupa data atau suatu algoritma operasi hitung dapat tersampaikan secara utuh, tuntas dan bermakna. Media TIK terutama komputer yang diantaranya terdapat Software program Microsoft Excel adalah sangat sesuai untuk upaya peningkatan mutu proses pembelajaran matematika terutama berkaitan dengan algoritma hitung dasar cara singkat.

Algoritma hitung dasar matematika sangat mutlak untuk dapat dikuasai oleh siswa semenjak berada di jenjang pendidikan SD. Pada proses pemahamannya tidak hanya dilakukan dengan menggunakan alat bantu atau media konkret, sesuai dengan kaidah keilmuan matematika yang bersifat abstrak. Terutama ketika siswa berupaya untuk dapat memiliki kemampuan terampil algoritma operasi hitung penjumlahan, pengurangan, perkalian, maupun pembagian ( porogapit) yang cukup abstrak sangat membutuhkan visualisasi simulasi yang representatif.

Beberapa contoh ilustrasi tahapan proses algoritma hitung dasar yang dihasilkan oleh siswa pada pembelajaran matematika sebelum menerapkan media komunikasi TIK berbasis komputer program Microsoft Excel terlihat pada gambar-gambar di bawah ini. Kemampuan terampil algoritma operasi hitung dasar matematika seperti tampak pada gambargambar dibawah ini menunjukan bahwa prosedur algoritma operasi hitung belum dapat dipahami dengan baik oleh siswa pada suatu kelas pembelajar. 


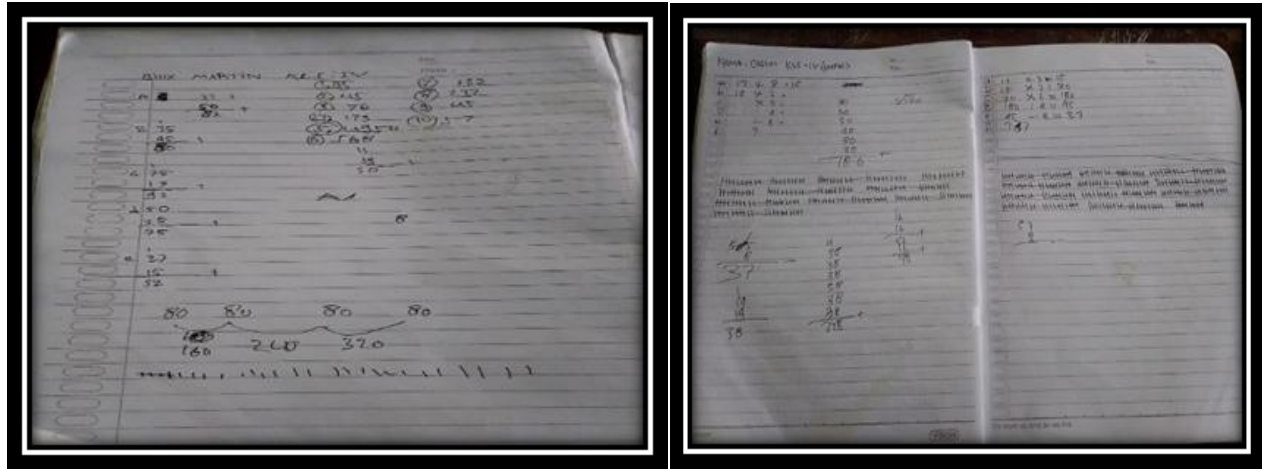

Gambar 3.1. Visualisasi beberapa proses algoritma hitung dasar hasil kerja siswa.

Pada kenyataanya penguasaan prosedural algoritma hitung dasar sebagai keterampilan dasar pembelajaran matematika, bagi kebanyakan guru ketika menyajikan pembelajarannya hanya memanfaatkan alat bantu atau media yang masih sangat sederhana hanya berupa papan tulis lengkap dengan kapur tulis maupun spidol sebagai sarana untuk menginformasikan tahapan-tahapan prosedural atau sistematikanya. Kegiatan pembelajaran yang demikian dianggap kurang mengikuti perkembangan model simulasi tahapan-tahapan prosedural algoritma suatu operasi hitung pada pembelajaran matematika sebagimana dikehendaki oleh tuntutan kebutuhan keterampilan di era digital milenial sebagai wujud dari implementasi era revolusi industri 4.0. yang semakin global di Abad 21. Model pembelajaran yang dikehendaki adalah model pembelajaran yang memaksimalkan pemberdayaan dalam penggunaan media TIK sesuai kemampuan penggunaan serta ketersediaan sarana yang dibutuhkan.

Meskipun algoritma penjumlahan, pengurangan, perkalian, dan pembagian cara singkat merupakan operasi hitung dasar matematika yang sederhana akan tetapi sangat mutlak untuk dikuasai secara tuntas 
oleh siswa ketika masih mengikuti belajar pada jenjang pendidikan SD sebagai pemahaman dan keterampilan awal operasi hitung pada pembelajaran matematika .

Dengan demikian dasar pemikiran atau ide dasar untuk dilakukanya penelitian dan pengembangan pemberdayaan manfaat media komunikasi pembelajaran oleh penulis adalah kepentingan kebaharuan untuk dapat menghasilkan mutu proses maupun hasil pembelajaran matematika dengan optimal. Melalui simulasi desain algoritma operasi hitung dasar pada pembelajaran matematika, siswa dapat paham serta terampil sistematika prosedural algoritma sebagai keterampilan dasar pembelajaran matematika. Sehingga ketika penerapannya untuk penyelesaian masalah yang ada pada soal-soal latihan pembelajaran matematika yang menghendaki proses kemampuan berpikir tingkat tinggi yang menerapkan operasi hitung penjumlahan, pengurangan, perkalian, dan pembagian ( porogapit) tidak akan lagi muncul masalah dalam hal kesiapan kompetensi keterampilan yang menjadi prasyaratnya. Selain dari ide dasar termaksud di atas, dengan diterapkanya suatu media TIK berbasis komputer program Microsoft Excel sebagai media komunikasi pelaksanaan pembelajaran maka bagi siswa akan terdampak pula pada pengenalan suatu media komunikasi digital sedini mungkin untuk kebutuhan kegiatan pemahaman materi pembelajaran matematika.

\section{Rancangan Karya Inovasi Pembelajaran}

Ketika terjadi suatu kegiatan pembelajaran akan terjadi hubungan komunikasi yang saling mengikat antara Siswa dengan Guru. Guru bertindak sebagai pengajar sedangkan siswa akan bertindak sebagai 
pembelajar. Secara tidak langsung hubungan keduanya akan dipengaruhi juga oleh berbagai faktor, diantaranya adalah media komunikasi. Pada kegiatan pembelajaran yang sangat sederhana media komunikasi dapat saja hanya berupa buku dan pensil atau papan tulis dengan kapur tulisnya.

Seiring perkembangan zaman, kebutuhan tingkat penguasaan siswa terhadap materi pembelajaran semakin tinggi tingkat pemaknaanya. Era digital milenial yang sangat global menghendaki hasil capaian pembelajaran yang penuh makna terhadap tuntutan kebutuhan kehidupan . Era revolusi indistri 4.0 menghendaki capaian kemampuan siswa dari kegiatan belajarnya menggambarkan suatu kemampuan yang terintegrasi dengan penerapan TIK.

Sebagai upaya maksimal pemenuhan capaian yang optimal untuk proses serta hasil pembelajaran matematika yang terintegrasi pengetahuan, pemahaman, bahkan keterampilan melalui pemberdayaan media TIK dilakukanlah penelitian untuk pengembangan penerapan media program Microsoft Excel sebagai media komunikasi pembelajaran matematika desain algoritma hitung dasar berbantuan program microsoft excel.
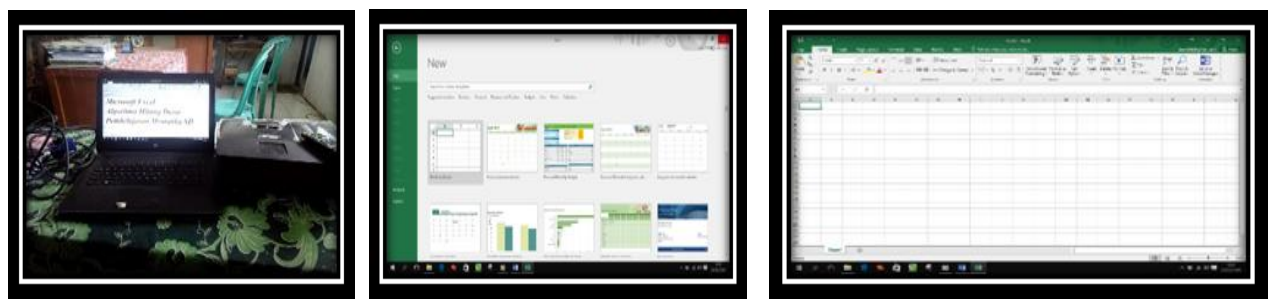

Gambar 3.2.

Perangkat TIK untuk media visualisasi presentasi materi pembelajaran.

Inovasi yang dilakukan penulis adalah desain simulasi proses algoritma hitung dasar sebagai keterampilan dasar matematika 
berbantuan media TIK berbasis komputer program microsoft excel. Dengan presentasi visualisasi simulasi yang dianggap mampu menarik perhatian siswa untuk pemahaman suatu prosedur algoritmik maka capaian hasil serapan pemahaman siswa akan teroptimalisasi. Siswa dilibatkan pada suatu proses pemahaman yang abstrak dengan batuan media komunikasi TIK komputer program Microsoft Excel sebagai program pilihan yang dianggap sesuai dengan konten matematika khususnya operasi hitung penjumlahan, pengurangan, perkalian, dan pembagian (porogapit).

Visualisasi simulasi proses algoritma hitung dasar sebagai keterampilan dasar pembelajaran matematika berbantuan media komunikasi lembar kerja ( work sheet) yang ada pada program Microsoft Excel akan dapat memaksimalkan visualisasi simulasi prosedur abstrak yang efisein dan efektif sebagai media komunikasi pembelajaran. Perangkat TIK yang digunakan dalam kegiatan penelitian dan pengembangan, diantaranya: 1. Komputer/ Leptop; 2. Infokus; 3. Layar presentasi; 4. Program Microsof Excel.

Dengan menggunakan perangkat yang tersedia dilakukan desain model presentasi visualisasi simulasi untuk proses algoritma penjumlahan, pengurangan, perkalian, atau pembagian ( porogapit). Dilaksanakan pula upaya peningkatan motivasi siswa dalam belajar matematika melalui penerapan beberapa simulasi desain kombinasi hitung dasar sebagai metode pembelajaran permainan matematika.

\section{Proses Penemuan Kebaharuan Karya Inovasi \\ 1. Tahap Identifikasi Media Komunikasi}

Berkaitan dengan media komunikasi komputer program microsoft excel yang digunakan pada suatu kegiatan inovasi pembelajaran 
dijelaskan oleh Yudhistira Ikranegara ( 2006: 11 ), bahwa aplikasi Microsoft Excel merupakan program yang memiliki kegunaan diantaranya untuk mempermudah dalam pengaturan layout dan format tabel, pencetakan, penggabungan tabel dan grafik, serta operasi data yang melibatkan beberapa sheet dan workbook. Berkaitan dengan pengembangan desain algoritma hitung dasar matematika, maka aplikasi microsoft excel akan sangat memungkinkan untuk diberdayakan penggunaanya.

Kondisi kompetensi siswa yang menunjukan suatu kepentingan yang sangat mendasar untuk dengan segera dilaksanakan suatu kegiatan yang bersifat terafis refresif dalam rangka meningkatkan mutu proses serta hasil pembelajaran matematika. Seperti yang telah dituliskan pada bagian terdahulu, kemampuan proses pembelajaran siswa untuk menerapkan suatu kemampuan terampil proses algoritma hitung penjumlahan, pegurangan, perkalian, dan pembagian ( porogapit) pada kenyataanya adalah sangat rendah. Dengan adanya kegunaan dari aplikasi Microsoft Excel seperti dituliskan di atas maka dianggap sesuai untuk memenuhi kebutuhan praktis media dalam kegiatan komunikasi presentasi pembelajaran matematika.

2. Tahap simulasi model inovasi

Model desain simulasi ilustrasi langkah-langkah sistematis proses algoritma hitung dasar matematika berbantuan media TIK program Microsoft Excel dalam kegiatan yang dianggap sebagai kegiatan penelitian ( research ) dan pengembangan (development) dikelompokan dalam beberapa model sebagai berikut: a. Model penjumlahan dengan cara pendek; b. Model pengurangan dengan cara pendek; c. Model perkalian dengan cara singkat; d. Model pembagian ( porogapit) dengan cara 
singkat (Gunanto dan Dhesy Adhalia, 2016); e. Model operasi hitung dasar cara singkat dalam metode permainan matematika (Erman Suherman Ar, dkk., 2001).

Beberapa model desain algoritma hitung dasar yang merupakan bentuk keterampilan awal harus dikuasai dengan benar oleh siswa semenjak berada pada jenjang pendidikan SD. Pemahaman terhadap konsep operasi hitung termaksud di atas serta terampil penerapanya ketika penyelesaian masalah yang termuat pada soal-soal latihan pembelajaran matematika adalah merupakan kemampuan prasyarat untuk dapat mengikuti proses pembelajaran matematika secara berkelanjutan. Ilustrasi visualisasi proses algoritma hitung dasar cara singkat yang dikembangkan dalam desain Worksheet Microsoft Excel adalah sebagai berikut:

a. Model penjumlahan dengan cara pendek;

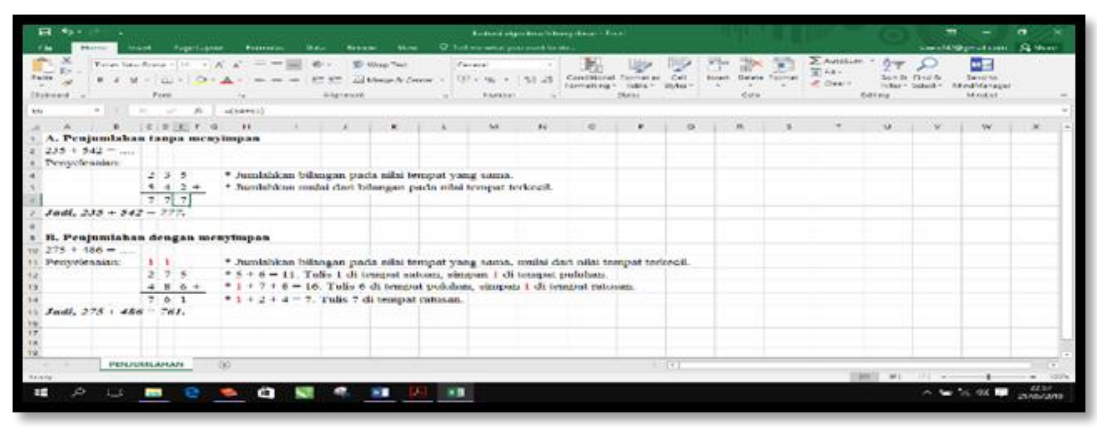

Gambar 3.3. Ilustrasi algoritma penjumlahan ( + ) cara pendek. b. Model pengurangan dengan cara pendek;

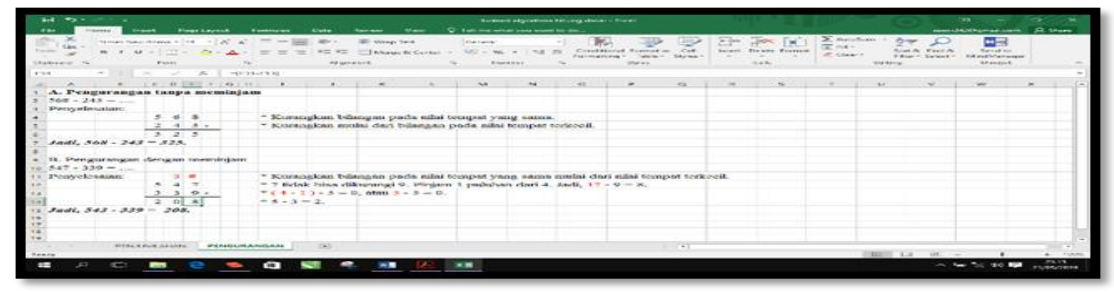

Gambar 3.4. Ilustrasi algoritma pengurangan ( - ) cara pendek. 


\section{Sawir}

c. Model perkalian dengan cara singkat;

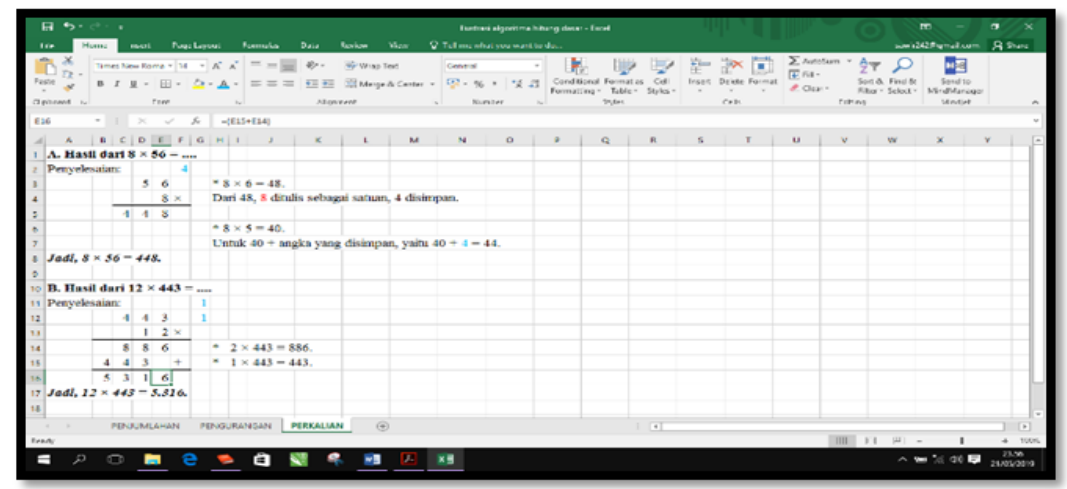

Gambar 3.5. Ilustrasi algoritma perkalian ( $x$ ) cara singkat.

d. Model pembagian ( porogapit) dengan cara singkat.

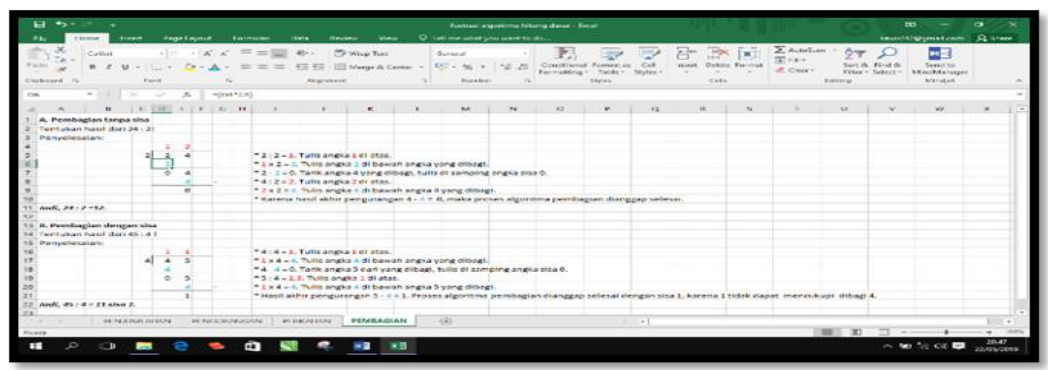

Gambar 3.6. Ilustrasi algoritma pembagian ( porogapit) cara singkat.

e. Model operasi hitung dasar cara singkat dalam metode permainan matematika.

Dikutip model permainan matematika dengan penyesuaian ke dalam model operasi hitung dasar matematika dari Erman Suherman ( 2001, hlm. 181 ), sebagai berikut " $A+3=B, B \times 2=C, C \times 6=D, D \div 4=$ $\mathrm{E}, \mathrm{E}-8=\mathrm{F}, \mathrm{F}=$ ?, untuk A merupakan bilangan awal yang dirahasiakan, sedangkan F merupakan bilangan yang dipublikasikan. 


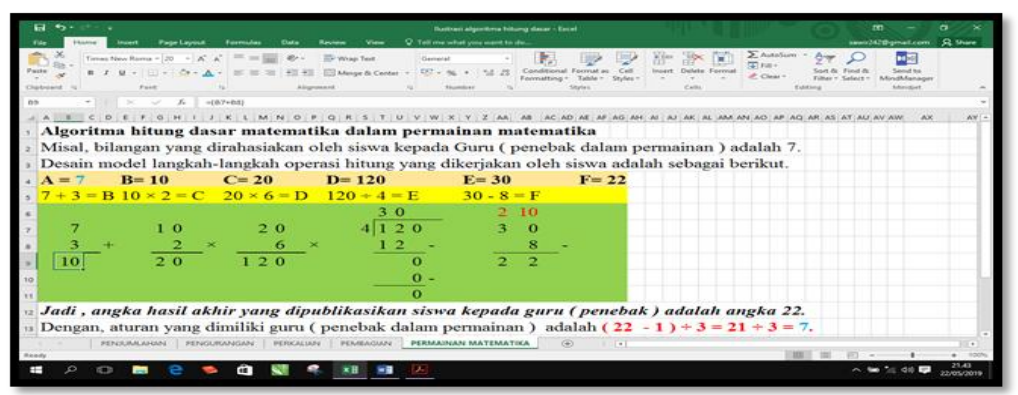

Gambar 3.7. Kombinasi algoritma hitung dasar dalam metode permainan matematika.

\section{Tahap Observasi Inovasi Media Komunikasi}

Kegiatan observasi terhadap kreasi desain media komunikasi program Microsoft Excel sebagai media pembelajaran operasi hitung $(+,-$, $\times$, dan $\div$ ) pembelajaran matematika dilaksanakan dengan fokus pengamatan aktivitas siswa ketika kegiatan pembelajaran matematika. Materi pembelajaran algoritma operasi hitung,,$+- \times$, dan $\div$ disajikan guru menggunakan media TIK komputer program Microsoft Excel secara visualisasi desain ilustrasi pada suatu kegiatan pembelajaran di kelas.

Pada tahap observasi berlangsung dilakukan kegiatan pengamatan aktivitas respon siswa belajar secara sistematis sebagai dasar pertimbangan tingkat keberdayaan media TIK komputer program Microsoft Excel terhadap mutu proses pembelajaran matematika konten algoritma operasi hitung,,$+- \times$, dan $\div$ bilangan cacah cara singkat .

4. Tahap Kreasi Media Komunikasi

Tahap kreasi dilaksanakan terhadap media komunikasi yang diimplementasikan ketika tahap observasi. Pada tahap kreasi guru memberikan suatu evaluasi terhadap penerapan media komunikasi TIK yang diterapkan. Kreasi dilaksanakan dengan memberikan penambahan 
perbaikan ilustrasi seperlunya juga dilakukan pengurangan ilustrasi yang dianggap kurang komunikatif. Guru memberikan apresiasi semua bentuk hasil tulisan siswa yang ada pada kertas kerja setelah mengikuti pembelajaran pada hasil kerja secara perorangan maupun kelompok belajar. Memberikan suatu motivasi untuk bersikap kritis dan kreatif sehingga dapat terampil berliterasi yang dianggap bermakna dalam upaya peningkatan dan pengembangan kemampuan menerima dan menyerap berbagai informasi aktual sebagai bentuk kecakapan Abad 21.

\section{Aplikasi Praktis dalam Pembelajaran}

Langkah-langkah kegiatan pembelajaran:

1. Awal kegiatan pembelajaran

- Guru menyapa siswa dengan salam, memeriksa absensi siswa.

- Siswa berdo'a bersama dipimpin seorang siswa.

- Siswa bersama menyanyikan lagu kebangsaan Indonesia Raya tiga stanza ciptaan W.R Soepratman, dipimpin seorang siswa sebagai dirigent.

- Guru memberikan apersepsi dengan cara tanya jawab secara klasikal terkait materi operasi hitung dasar matematika.

- Guru membacakan tujuan pembelajaran yang harus dicapai siswa.

- Guru memberikan motivasi dengan menjelaskan makna dari tujuan pembelajaran yang telah disampaikan.

2. Inti kegiatan pembelajaran

- Guru menyampaikan materi pembelajaran tentang operasi hitung dasar matematika. Pembelajaran dilakukan dengan tanya jawab menggunakan contoh soal yang didesain pada visualisasi ilustrasi langkah-langkah proses algoritma operasi hitung penjumlahan, 
pengurangan, perkalian, dan pembagian (porogapit) secara sistematis. Digunakan desain materi pembelajaran dalam media TIK program Microsoft Excel dan ditayangkan secara klasikal menggunakan tayangan infokus.

- Siswa secara perorangan membuat catatan dari hasil menyimak serta tanya jawab secara klasikal pada buku kerja masing-masing.

- Siswa secara berkelompok mengadakan diskusi kelompok dengan materi yang telah disiapkan guru.

- Setiap kelompok siswa diberi kesempatan untuk mempresentasikan hasil diskusi kelompok masing-masing dengan bimbingan operasional presentasi dalam TIK komputer program Microsoft Excel oleh Guru secara langsung dan terpusat.

3. Penutup kegiatan pembelajaran

- Guru memberikan evaluasi dan penguatan capaian pembelajaran dengan metode permainan matematika.

- Guru membimbing siswa mengadakan refleksi atas kegiatan pembelajaran yang telah dilaksanakan siswa.

- Guru menutup pembelajaran dengan memberikan bimbingan terhadap siswa untuk menyimpulkan materi pembelajaran yang telah dipelajari.

\section{E. Hasil dan Pembahasan}

Media komunikasi TIK komputer program Microsoft Excel diterapkan untuk media komunikasi informasi visualisasi presentasi langkah-langkah sistematis pada proses algoritma hitung dasar matematika. Dasar pertimbangan simpulan keberdayaan serta makna penggunaan media dalam pembelajaran yang dilaksanakan dapat dilihat 
pada nilai proses serta nilai akhir capaian siswa terhadap pembelajaran yang dilaksanakan.

1. Hasil Observasi Pembelajaran

Observasi terhadap berlangsungnya pembelajaran dilaksanakan dengan cara pengumpulan angket terhadap semua siswa sebagai responden. Berikut data hasil angket yang disebarkan dan dikumpulkan dengan jawaban angket secara tertutup. Angket berisikan pertanyaan terkait dengan penggunaan media komunikasi pembelajaran. Media komunikasi komputer program microsoft excel yang diberdayakan memuat konten visualisasi simulasi desain algoritma penjumlahan, pengurangan, perkalian, dan pembagian ( porogapit ) cara singkat. Instrumen angket diserahkan kepada siswa kelas IV UPTD SDN I Tanjungkerta tahun pelajaran 2018/ 2019 sebanyak 24 siswa sebagai responden untuk dilengkapi sejak awal dilaksanakan kegiatan penelitian dan baru dikembalikan kepada guru secara tertutup ketika akhir kegiatan penelitian dilaksanakan.

Tabel 3.1.

Hasil angket pembelajaran matematika ( $\mathrm{n}=24$ siswa)

\begin{tabular}{|c|c|c|c|c|c|}
\hline No. & Pertanyaan & $\begin{array}{l}\text { Pilihan } \\
\text { Sangat } \\
\text { Setuju } \\
\text { ( Skor } 2 \\
\text { ) }\end{array}$ & $\begin{array}{l}\text { waban } \\
\text { Setuju } \\
\text { ( Skor } \\
1 \text { ) }\end{array}$ & $\begin{array}{l}\text { Jml. } \\
\text { Skor }\end{array}$ & $\begin{array}{c}\text { Rata- } \\
\text { rata } \\
\text { Skor }\end{array}$ \\
\hline 1 & $\begin{array}{l}\text { Apakah kamu merasa senang } \\
\text { belajar } \\
\text { matematika dengan media } \\
\text { komputer }\end{array}$ & 22 & , & 46 & 192 \\
\hline 2 & $\begin{array}{l}\text { program microsof excel? } \\
\text { Apakah media komputer program } \\
\text { microsoft excel mudah digunakan }\end{array}$ & 21 & 3 & 45 & 1,88 \\
\hline
\end{tabular}


sebagai media pembelajaran

matematika?

Apakah dengan media komputer

3 program

microsoft excel konten materi

pembelajaran

23

1

47

1,96

hitung dasar mudah dimengerti?

Apakah dengan media komputer

4 program

microsoft excel dapat membantu

19

5

$43 \quad 1,79$

memudahkan penyelesaian masalah

pembelajaran matematika?

Apakah kamu setuju bahwa media

5 komputer

program microsoft excel mampu

membantu

siswa belajar proses hitung dasar

$\begin{array}{llll}21 & 3 & 45 & 1,88\end{array}$

matematika?

Jumlah

Rata-rata

2. Hasil penilaian proses pembelajaran

Penilaian proses pembelajaran diarahkan terhadap aktivitas unjuk kerja siswa selama berlangsungnya kegiatan pembelajaran dan respon siswa terhadap tugas mandiri yang harus diselesaikan di rumah untuk melengkapi tugas-tugas yang belum terselesaikan ketika melaksanakan proses pembelajaran di sekolah. Dengan demikian pengamatan dilaksanakan guru terhadap aktivitas unjuk kerja siswa secara individu pada suatu kelas belajar, kelompok kecil, dan respon individu siswa terhadap tugas-tugas mandiri. Pengamatan dilaksanakan secara langsung ketika siswa beraktivitas belajar maupun dengan cara tidak langsung melalui rekaman video dan fotto yang dapat dibuat guru ketika 
melaksanakan pengamatan. Berikut ini data nilai pengamatan aktivitas siswa selama proses pembelajaran.

Tabel 3.2.

Nilai pengamatan unjuk kerja siswa

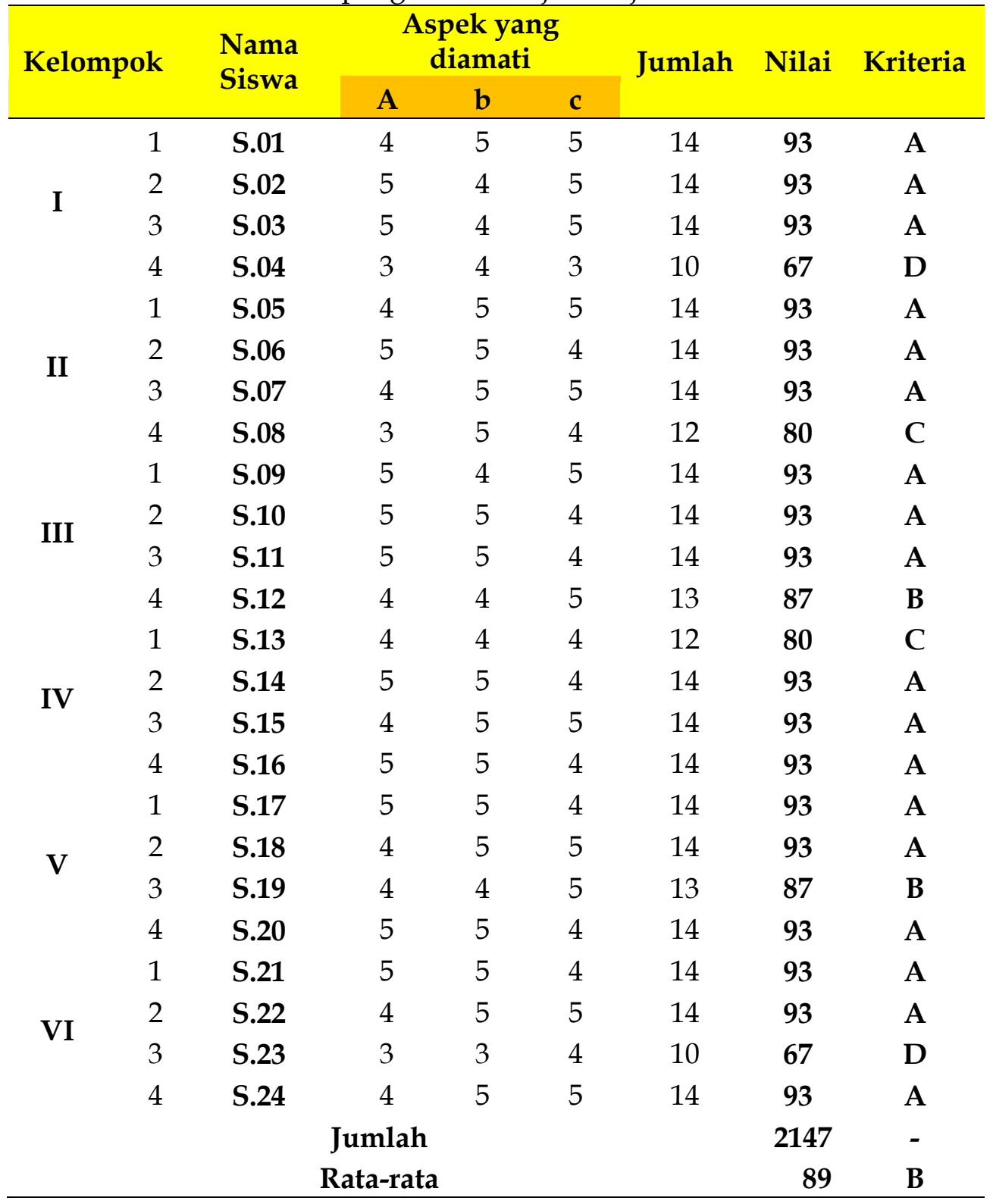

Keterangan: 
a. Aspek yang dinilai/ diamati: $\mathrm{a}=$ Kerja sama dalam kelompok; $\mathrm{b}=$ Sistematika algoritma hitung dasar; $\mathrm{c}=$ Presentasi hasil kerja kelompok.

b. Bobot skor: Sangat Baik $=5$; Baik $=4$; Cukup= 3; Kurang= 2; Sangat Kurang=1.

c. $\quad$ Nilai $=\underline{\text { Skor Perolehan }} \times 100$ 15

d. Kriteria dan predikat nilai ( catatan: KKM mapel matematika kelas IV adalah 65):

$\mathrm{E} \leq 64 ; 65 \leq \mathrm{D} \leq 73 ; 74 \leq \mathrm{C} \leq 82 ; 83 \leq \mathrm{B} \leq 91 ; 92 \leq \mathrm{A} \leq 100$.

$\mathbf{A}=$ Sangat baik; $\mathbf{B}=$ Baik; $\mathbf{C}=$ Cukup; $\mathbf{D}=$ Kurang; $\mathbf{E}=$ Sangat kurang.

3. Perolehan nilai hasil pembelajaran awal dan akhir kegiatan penelitian

Untuk mendapatkan data nilai hasil akhir pembelajaran dengan menerapkan media TIK komputer program Microsoft Excel sebagai media komunikasi desain algoritma penjumlahan, pengurangan, perkalian, dan pembagian (porogapit) cara singkat dilaksanakan tes akhir kegiatan penelitian dengan teknik tes terhadap kompetensi pengetahuan. Sebagai bahan acuan pembahasan nilai hasil pembelajaran aspek pengetahuan, dilaksanakan pula tes pengetahuan awal yang dimiliki siswa terhadap penguasaan penerapan keterampilan algoritma penjumlahan, pengurangan, perkalian, dan pembagian cara singkat untuk penyelesaian masalah pada soal-soal latihan pembelajaran matematika.

Instrumen penilaian yang digunakan yaitu berupa naskah soal tes dalam bentuk pilihan ganda sebanyak 5 nomor soal, isian singkat sebanyak 3 nomor soal, dan uraian terbatas sebanyak 2 nomor soal, sehingga instrumen soal yang disusun terdiri dari 10 nomor soal. Skor maksimal perolehan adalah 17, dengan rincian: soal PG $=5 \times 1=5$, soal isian singkat $=3 \times 2=6$, dan soal uraian terbatas $=2 \times 3=6$. Konten materi substansi yang diajarkan yaitu operasi hitung bilangan cacah. Naskah instrumen penilaian aspek pengetahuan yang digunakan ketika tes awal dan tes akhir pembelajaran yaitu naskah instrumen penilaian yang 
berbeda tetapi sama untuk indikator pencapaian kompetensi dan bentuk serta bobot skor tiap soalnya.

\section{Tabel 3.3.}

Nilai Tes Pengetahuan Awal Kegiatan Penelitian

\begin{tabular}{cccccl}
\hline Nomor & Nama Siswa & Skor & Nilai & Kriteria & Keterangan \\
\hline 1 & S.01 & 14 & 82 & C & Cukup \\
2 & S.02 & 13 & 76 & C & Cukup \\
3 & S.03 & 12 & 71 & D & Kurang \\
4 & S.04 & 10 & 59 & E & Sangat kurang \\
5 & S.05 & 12 & 71 & D & Kurang \\
6 & S.06 & 10 & 59 & E & Sangat kurang \\
7 & S.07 & 12 & 71 & D & Kurang \\
8 & S.08 & 10 & 59 & E & Sangat kurang \\
9 & S.09 & 14 & 82 & C & Cukup \\
10 & S.10 & 12 & 71 & D & Kurang \\
11 & S.11 & 10 & 59 & E & Sangat kurang \\
12 & S.12 & 14 & 82 & C & Cukup \\
13 & S.13 & 10 & 59 & E & Sangat kurang \\
14 & S.14 & 14 & 82 & C & Cukup \\
15 & S.15 & 14 & 82 & C & Cukup \\
16 & S.16 & 12 & 71 & D & Kurang \\
17 & S.17 & 10 & 59 & E & Sangat kurang \\
18 & S.18 & 12 & 71 & D & Kurang \\
19 & S.19 & 12 & 71 & D & Kurang \\
20 & S.20 & 12 & 71 & D & Kurang \\
21 & S.21 & 10 & 59 & E & Sangat kurang \\
22 & S.22 & 10 & 59 & E & Sangat kurang \\
23 & S.23 & 10 & 59 & E & Sangat kurang \\
24 & S.24 & 12 & 71 & D & Kurang \\
& Jumlah & & $\mathbf{1 6 5 3}$ & - & - \\
& Rata-rata & & $\mathbf{6 9}$ & D & Kurang \\
\hline
\end{tabular}


Perolehan nilai pengetahuan hasil tes akhir kegiatan penelitian terhadap 24 siswa yang dianggap sebagai subyek kegiatan penelitian adalah sebagai berikut.

Tabel 3.4.

Nilai Tes Pengetahuan Akhir Kegiatan Penelitian

\begin{tabular}{cccccl}
\hline Nomor & Nama & $\begin{array}{c}\text { Skor } \\
\text { Perolehan }\end{array}$ & $\begin{array}{c}\text { Nilai } \\
\text { Akhir }\end{array}$ & Kriteria & Keterangan \\
\hline 1 & S.01 & 16 & 94 & A & Sangat Baik \\
2 & S.02 & 14 & 82 & C & Cukup \\
3 & S.03 & 14 & 82 & C & Cukup \\
4 & S.04 & 12 & 71 & D & Kurang \\
5 & S.05 & 15 & 88 & B & Baik \\
6 & S.06 & 15 & 88 & B & Baik \\
7 & S.07 & 15 & 88 & B & Baik \\
8 & S.08 & 14 & 82 & C & Cukup \\
9 & S.09 & 15 & 88 & B & Baik \\
10 & S.10 & 14 & 82 & C & Cukup \\
11 & S.11 & 12 & 71 & D & Kurang \\
12 & S.12 & 14 & 82 & C & Cukup \\
13 & S.13 & 14 & 82 & C & Cukup \\
14 & S.14 & 15 & 88 & B & Baik \\
15 & S.15 & 16 & 94 & A & Sangat Baik \\
16 & S.16 & 15 & 88 & B & Baik \\
17 & S.17 & 14 & 82 & C & Cukup \\
18 & S.18 & 15 & 88 & B & Baik \\
19 & S.19 & 13 & 76 & C & Cukup \\
20 & S.20 & 16 & 94 & A & Sangat Baik \\
21 & S.21 & 13 & 76 & C & Cukup \\
22 & S.22 & 13 & 76 & C & Cukup \\
23 & S.23 & 12 & 71 & D & Kurang \\
24 & S.24 & 13 & 76 & C & Cukup \\
& Jumlah & & B & Baik \\
\hline
\end{tabular}


Keterangan:

a. Nilai Akhir $=\underline{\text { Skor perolehan }} \times 100$

17

b. Kriteria dan predikat nilai (catatan: KKM mapel matematika kelas IV adalah 65 ).

Kriteria: $\mathbf{E} \leq 64 ; 65 \leq \mathrm{D} \leq 73 ; 74 \leq \mathbf{C} \leq 82 ; 83 \leq \mathbf{B} \leq 91 ; 92 \leq \mathbf{A} \leq 100$.

Predikat: $\mathbf{A}=$ Sangat baik; $\mathbf{B}=$ Baik; $\mathbf{C}=$ Cukup; $\mathbf{D}=$ Kurang; $\mathbf{E}=$ Sangat kurang

\section{Analisis Data Hasil Kegiatan Pengembangan}

1. Analisis data hasil angket.

Untuk mengetahui ketertarikan siswa terhadap kegiatan pembelajaran dengan menerapkan pengembangan desain algoritma hitung dasar cara singkat berbantuan program microsoft excel dilakukan kegiatan observasi. Kegiatan observasi dilengkapi dengan menggunakan instrumen angket yang harus direspon oleh setiap siswa. Berdasarkan data hasil observasi melalui angket tertutup yang diberikan kepada sebanyak 24 responden dilakukan analisis sebagai berikut.

\section{Tabel 3.5.}

Analisis hasil angket observasi pembelajaran

\begin{tabular}{|c|c|c|c|c|c|c|c|c|c|}
\hline \multirow{3}{*}{$\begin{array}{l}\mathrm{N} \\
\mathrm{o} .\end{array}$} & \multirow{3}{*}{ Pertanyaan } & \multicolumn{6}{|c|}{ Pilihan Jawaban } & \multirow{3}{*}{$\begin{array}{c}\mathrm{Jm} \\
1 \\
\mathrm{Sk} \\
\mathrm{r}\end{array}$} & $\begin{array}{c}\text { Prosenta } \\
\text { se }\end{array}$ \\
\hline & & \multicolumn{3}{|c|}{$\begin{array}{c}\text { Sangat Setuju } \\
\text { Sk }\end{array}$} & \multicolumn{3}{|c|}{ Setuju } & & $(\%)$ \\
\hline & & $\begin{array}{c}\mathrm{Jm} \\
1 .\end{array}$ & $\begin{array}{l}\text { r. } \\
2\end{array}$ & $\%$ & $\begin{array}{l}\mathrm{Jm} \\
1\end{array}$ & $\begin{array}{c}\text { Skr } \\
1\end{array}$ & $\%$ & & $\begin{array}{c}\text { Partisipa } \\
\text { si }\end{array}$ \\
\hline 1 & $\begin{array}{l}\text { Apakah kamu merasa } \\
\text { senang belajar } \\
\text { matematika dengan } \\
\text { media komputer } \\
\text { program } \\
\text { microsof excel? }\end{array}$ & 22 & 44 & $\begin{array}{l}91,6 \\
7\end{array}$ & 2 & 2 & 8,33 & 46 & 95,83 \\
\hline 2 & $\begin{array}{l}\text { Apakah media } \\
\text { komputer program } \\
\text { microsoft excel mudah } \\
\text { digunakan sebagai }\end{array}$ & 21 & 42 & $\begin{array}{l}87,5 \\
0\end{array}$ & 3 & 3 & $\begin{array}{l}12,5 \\
0\end{array}$ & 45 & 93,75 \\
\hline
\end{tabular}


$3 \quad$ Apakah dengan media

$\begin{array}{lllll}23 & 46 & 95,8 & 1 & 1\end{array}$

komputer program

$4,17 \quad 47 \quad 97,92$

microsoft excel konten

materi pembelajaran

hitung dasar mudah

dimengerti?

$4 \quad$ Apakah dengan media

komputer program

19

microsoft excel dapat

membantu

memudahkan

penyelesaian masalah

pembelajaran

matematika?

5 Apakah kamu setuju

bahwa media

komputer

program microsoft excel

0

0

mampu membantu

siswa belajar proses

hitung dasar

matematika?

Jumlah

Rata-rata

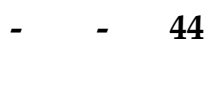

$-\quad-\quad 88$
$20,8 \quad 43 \quad 89,58$

3

$7 \quad 3$

Melihat hasil analisis yang ada pada tabel di atas dapat diilustrasikan menjadi visualisasi dalam bentuk grafik berikut ini. Pada grafik yang ada terlihat lebih jelas kondisi motivasi siswa terhadap pembelajaran dengan penerapkan media TIK komputer program Microsoft Excel untuk pembelajaran matematika tentang algoritma penjumlahan, pengurangan, perkalian, dan pembagian ( porogapit) cara singkat dengan materi substansi bilangan cacah di kelas IV SD Negeri 1 Tanjungkerta tahun pelajaran 2018/ 2019. 


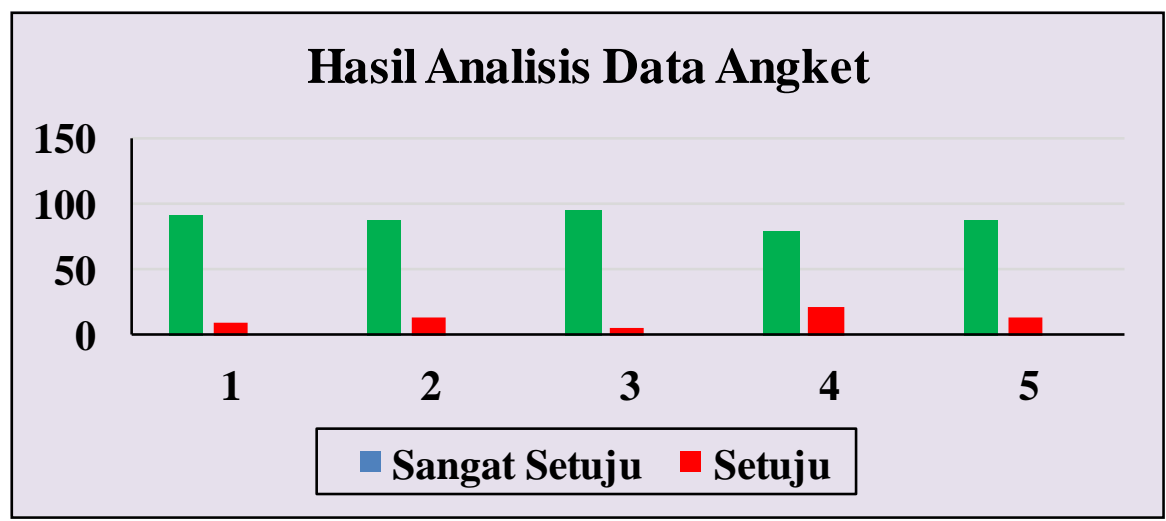

Gambar 3.8. Gambar grafik data angket observasi pelaksanaan pembelajaran.

Proses pembelajaran matematika dengan menerapkan media TIK komputer program Microsoft Excel sangat disenangi siswa, dengan demikian dianggap efektif terhadap pembelajaran. Untuk mau melaksanakan suatu kegiatan, apapun bentuk kegiatanya, akan merasa ringan dalam pelaksanaanya jika kondisi psikis pada kondisi rasa senang. Dengan kondisi siswa sangat senang terhadap kegiatan pembelajarn matematika tentunya pembelajaran akan dapat diharapkan untuk tercapai secara optimal ketuntasanya.

Media TIK komputer program Microsoft Excel dianggap sangat mudah untuk diterapkan sebagai media komunikasi pembelajaran, meskipun dalam pelaksanaan pembelajaran untuk operasional pemindaian informasi tetap dalam bimbingan guru. Hal ini sesuai dengan kenyataan siswa SD yang umumnya berada pada tahap awal pengenalan penggunaan media komputer. Dengan awal yang baik, yaitu siswa merasa mudah untuk menggunakanya, maka besar harapan kebermaknaan media yang dipilih akan sangat besar manfaatnya bagi upaya peningkatan keberhasilan suatu pembelajaran. 
Penerapan program Micfrosoft Excel untuk media pembelajaran sangat refresentatif un tuk mengilustrasikan konten materi pembelajaran. Ketuntasan materi pembelajaran dapat tersampaikan secara utuh. Pembelajaran akan optimal karena materi dapat tersampaikan secara utuh dengan media pembelajaran program Microsoft Excel. Media mapu merefresentasikan konten materi yang dianggap abstrak, yaitu materi yang dianggap tidak mampu jika diupayakan penyampaianya menggunakan media konkret.

Media Microsoft Excel sangat membantu siswa ketika menyelesaikan masalah yang termuat pada soal-soal matematika. Dengan media yang ada proses penyelesaian masalah sangat terbantu. Siswa merasa sangat terbatu puntuk enemukan penyelesaian permasalahan yang sedang dipelajari, dengan tetap tidak akan mengakibatkan ketergantungan dalam penggunaaanya. Hal ini dapat diantisipasi dengan tetap pada pendampingan guru ketika proses penggunaanya.

Secara keseluruhan siswa merasakan sangat setuju bahwa pembelajaran matematika sedapat mungkin selalu menggunakan media komputer yang diantaranya terdapat program Microsoft Excel yang sangat membantu proses berpikir siswa ketika kegiatan pembelajaran.

2. Analisis data hasil pengamatan kegiatan pembelajaran

Pengamatan terhadap aktivitas unjuk kerja siswa selama proses pembelajaran diarahkan terhadap beberapa aspek diantaranya pada aktivitas kerjasama yang dilakukan siswa dalam kelompok-kelompok kecil maupun perorangan, perolehan hasil ilustrasi sistematika materi pembelajaran yang terdapat di dalam lembar kerja yang dibuat siswa pada kelompoknya juga pada buku kerja pribadinya masing-masing, serta 
aktivitas setiap siswa ketika kegiatan presentasi hasil kerja kelompok di depan kelas pembelajaran baik itu aktivitas pribadi maupun aktivitas kelompok.

Kegiatan yang diamati merupakan kegiatan siswa secara efektif kegiatan edukatif siswa dalam kaitan penerapan media komunikasi pembelajaran program Microsoft Excel untuk memahami konsep hitung dasar matematika. Kegiatan pembelajaran yang diamati secara menyeluruh semenjak dilaksanakannya kegiatan penelitian dan pengembangan hingga terselesaikanya kegiatan.

Data ilustrasi hasil pengamatan kegiatan seluruh siswa ketika pembelajaran dapat dilihat partisipasi aktivitasnya sebagai berikut.

Tabel 3.6.

Data pengamatan aktivitas siswa ketika proses pembelajaran

\begin{tabular}{|c|c|c|c|}
\hline Nomor & Aspek yang diamati & $\begin{array}{l}\text { Rerata skor } \\
\text { perolehan }\end{array}$ & Prosentase \\
\hline 1 & $\begin{array}{l}\text { Kerja sama dalam } \\
\text { kelompok. }\end{array}$ & 4,33 & 86,60 \\
\hline 2 & $\begin{array}{l}\text { Sistematika algoritma } \\
\text { hitung dasar. }\end{array}$ & 4,62 & 92,40 \\
\hline 3 & $\begin{array}{lll}\text { Presentasi } & \text { hasil } & \text { kerja } \\
\text { kelompok. } & & \end{array}$ & 4,45 & 89,00 \\
\hline
\end{tabular}

Hasil analisis data pengamatan diilustrasikan dalam visualisasi gambar berikut ini. 


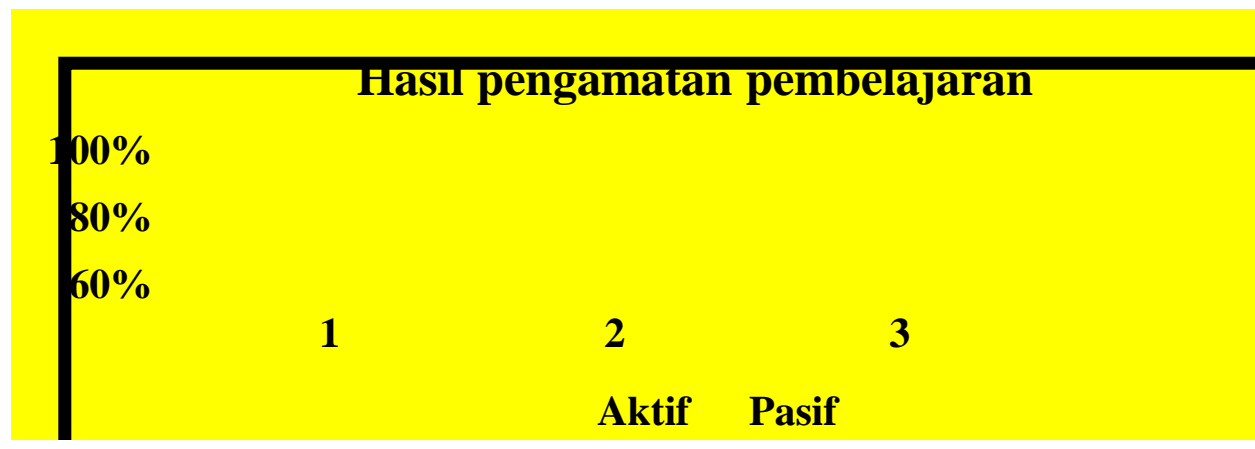

Keterangan: 1 = Kerja sama dalam kelompok.

2 = Sistematika algoritma hitung dasar.

$3=$ Presentasi hasil kerja kelompok.

Gambar 3.9. Grafik data hasil pengamatan aktivitas pembelajaran.

Partisipasi siswa terhadap kegiatan pembelajaran menunjukan tingkat partisipasi yang tinggi. Siswa menunjukan prosentase partisipasi aktif yang sangat signifikan. Hanya sebagian kecil siswa yang berada pada aktivitas partisipasi pasif, hal demikian muncul memang sesuai dengan kondisi siswa SD yang masih berada pada kemampuan awal untuk mengenal penggunaan media komputer microsoft excel sebagai media komunikasi informasi untuk kegiatan pembelajaran matematika. Secara umum segala bentuk pengalaman yang didapat selama mengikuti pembelajaran akan merupakan pengalaman yang sangat bermakna bagi semua siswa sebagai kecakapan hidup.

Pelaksanaan suatu kegiatan pembelajaran yang dalam prosesnya terintegrasi penerapan media yang dianggap sangat bermakna untuk pemenuhan kebutuhan aktivitas kehidupan akan menjadikan suatu pembelajaran yang efektif. Media TIK komputer program Microsoft Excel dapat dianggap sangat efektif jika dikuasai penggunaanya sebagai bekal pemenuhan tantangan era digital milenial sebagai era revolusi industri 4.0 yang semakin mengglobal. 
3. Analisis data hasil pengetahuan awal dan akhir kegiatan penelitian.

Dilakukan analisis terhadap capaian nilai awal kompetensi pengetahuan sebagai dasar simpulan signifikasi perubahan keberpengaruhan media desain algoritma hitung dasar yang diterapkan pengembanganya.

Tabel 3.7.

Analisis nilai pengetahuan awal kegiatan penelitian

\begin{tabular}{|c|c|l|c|c|}
\hline Nomor & Kriteria & \multicolumn{1}{|c|}{ Predikat } & Jumlah & Prosesntase ( \% ) \\
\hline 1 & A & Sangat Baik & 0 & 0 \\
\hline 2 & B & Baik & 0 & 0 \\
\hline 3 & C & Cukup & 6 & 25,00 \\
\hline 4 & D & Kurang & 9 & 37,50 \\
\hline 5 & E & Sangat Kurang & 9 & 37,50 \\
\hline \multicolumn{2}{|r|}{ Jumlah } & $\mathbf{2 4}$ & $\mathbf{1 0 0}$ \\
\hline \multicolumn{2}{|r|}{ Hasil analisis capaian nilai awal pengetahuan tervisualisasi } \\
\hline
\end{tabular}

sebagai berikut.

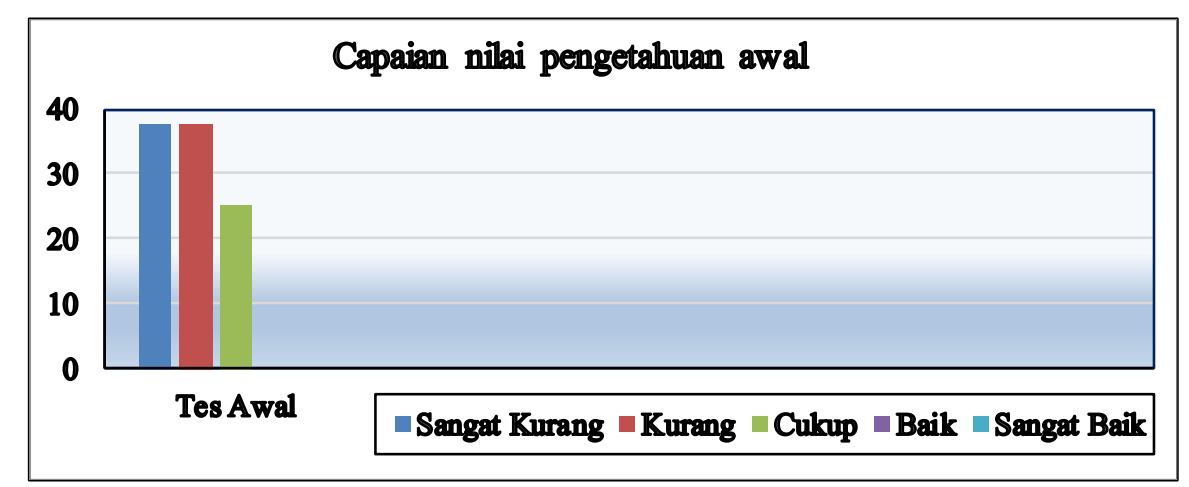

Gambar 3.10: Grafik prosentase capaian awal nilai pengetahuan. 
Dari nilai kompetensi pengetahuan yang dimiliki siswa untuk menerapkan algoritma operasi hitung penjumlahan, pengurangan, perkalian, serta pembagian sebelum memberdayakan media program microsoft excel sebagai media komunikasi visualisasi ternyata hasil belajar siswa sangat rendah. Dari 24 siswa hanya 6 siswa memiliki kompetensi cukup sedangkan sisanya memiliki kompetensi kurang bahkan sangat kurang. Artinya hanya sebesar 25\% dari sejumlah 24 siswa yang mampu menyelesaikan masalah pada soal-soal matematika yang membutuhkan penerapan algoritma hitung dasar pembelajaran matematika.

Diperoleh data hasil akhir pembelajaran seperti terlihat pada tabel berikut. Data nilai hasil akhir diperoleh dari tes pengetahuan yang dilaksanakan setelah akhir kegiatan penelitian pembelajaran dengan penerapan media TIK komputer program Microsoft Excel sebagai media komunikasi visualisasi desain algoritma operasi hitung dasar matematika.

Tabel 3.8.

Data nilai hasil pengetahuan akhir kegiatan penelitian

\begin{tabular}{|c|c|c|c|c|}
\hline Nomor & Kriteri & Predikat & Jumlah & Prosesntase \\
\hline 1 & $\mathrm{~A}$ & Sangat Baik & 3 & 12,50 \\
\hline 2 & B & Baik & 7 & 29,17 \\
\hline 3 & $\mathrm{C}$ & Cukup & 11 & 45,83 \\
\hline 4 & $\mathrm{D}$ & Kurang & 3 & 12,50 \\
\hline \multirow[t]{2}{*}{5} & E & Sangat Kurang & 0 & 0,00 \\
\hline & & Jumlah & 24 & 100,00 \\
\hline
\end{tabular}

Berikut ini visualisasi capaian nilai akhir pengetahuan kegiatan pembelajaran dengan penerapan pengembangan media desain algoritma hitung dasar cara singkat berbantuan program microsoft excel . 


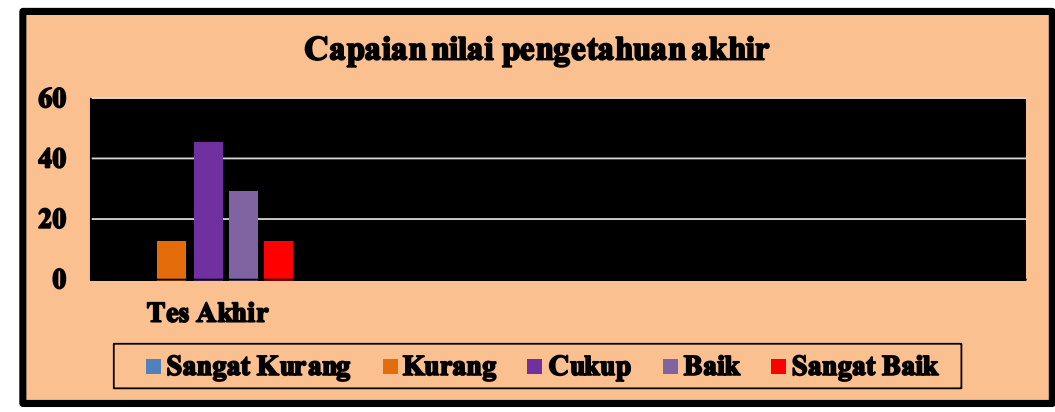

Gambar 3.11. Grafik prosentase capaian nilai akhir pengetahuan.

Siswa dengan capaian predikat sangat baik, baik, dan cukup untuk nilai pengetahuan sebagai nilai hasil pembelajaran akhir kegiatan penelitian menunjukan perolehan rata-rata prosentase sebesar $83 \%$ (kriteria B, predikat Baik) maka pembelajaran secara klasikal dianggap tuntas. Siswa dengan capaian predikat kurang ditindaklanjuti dalam proses perbaikan atau remidial individual.

Tingkat prosentase predikat kurang untuk capaian nilai pengetahuan dianggap tidak berpengaruh terhadap keberdayaan penerapan media komunikasi desain algoritma penjumlahan, pengurangan, perkalian, dan pembagian cara singkat berbantuan program microsoft excel. Keberhasilan penerapan media program Microsoft Excel terhadap pembelajaran matematika dianggap bermakna diperkuat pula dengan tidak adanya predikat sangat kurang terhadap nilai pengetahuan hasil pembelajaran akhir kegiatan penelitian.

Analisis data hasil penelitian menunjukan, bahwa penerapan media komunikasi program Microsoft Excel sebagai media komunikasi pembelajaran matematika dianggap berhasil. Pembelajaran matematika menunjukan kegiatan pembelajaran yang bermakna dengan menerapkan media desain algoritma hitung dasar cara singkat berbantuan program 
Microsoft Excel. Siswa aktif mengkritisi, mengkreasi, berkomunikasi, dan berkolaborasi dalam kegiatan pembelajaran. Situasi pembelajaran menjadi menyenangkan siswa dengan penerapan media pembelajaran yang mampu memberikan motivasi untuk belajar matematika labih lanjut. siswa menjadi lebih kreatif ketika aktivitas proses berpikir dan berlatih suatu kompetensi keterampilan yang bermakna. Kegiatan pembelajaran dianggap efektif dengan hasil belajar pengetahuan siswa yang melampaui batas ketuntasan capaian minimal.

\section{F. Penutup}

Penerapan media desain algoritma penjumlahan, pengurangan, perkalian, dan pembagian ( porogapit) cara singkat berbantuan media komunikasi program microsoft excel efektif terhadap peningkatan motivasi siswa terhadap proses pembelajaran matematika. Keefektifan ini ditandai dengan adanya motivasi siswa untuk belajar matematika yang tinggi serta adanya aktivitas belajar bermakna bagi siswa pembelajar. Penerapan media desain algoritma penjumlahan, pengurangan, perkalian, dan pembagian ( porogapit) cara singkat berbantuan media komunikasi program microsoft excel adalah sangat efektif terhadap peningkatan kompetensi keterampilan untuk penyelesaian masalah dalam soal-soal matematika. Hasil tes pengetahuan menunjukan pencapaian yang optimal setelah pelaksanaan kegiatan penelitian terselesaikan.

Disarankan kepada guru dapat melaksanakan kegiatan pembelajaran menggunakan media pembelajaran seperti yang telah digunakan penulis untuk pembelajaran dengan materi yang lebih memungkinkan kesesuaianya. Peneliti agar dapat melakukan kegiatan penelitian dan pengembangan lebih lanjut dari hasil kegiatan penelitian 
yang penulis dapatkan. Semua siswa anggaplah bahwa kegiatan pembelajaran yang telah selesai dilaksanakan merupakan pengalaman belajar yang sangat bermakna untuk dapat mengikuti pembelajaran matematika secara berkelanjutan. Lembaga sekolah untuk dapat mengakomodir segala kebutuhan yang harus dilengkapi dalam penerapan desain algoritma hitung dasar matematika berbantuan media komputer program microsoft excel sebagai media komunikasi visualisasi pembelajaran.

\section{Ucapan Terimakasih}

Saya sangat berterimakasih kepada Kepala Sekolah, rekan Guru, Pustakawan, dan Karyawan di UPTD SD Negeri 1 Tanjungkerta, yang telah berpartisipasi terhadap kegiatan penelitian ini.

\section{Daftar Pustaka}

Agustinawati.,S., dan Nugroho., G. K. ( 2013 ). Pembuatan Media Pembelajaran Microsoft Excel Pada Sekolah Menengah Pertama Negeri 2 Tawangmangu; Journal Speed -Sentra Penelitian Engineering dan Edukasi - Volume 5 No 4 - 2013 - ijns.org; ISSN : 1979-9330 (Print)-2088-0154(Online); http://www.ijns.org/journal/index.php/speed/article/viewFile $/ 1277 / 1265$

Ar., E. S., dkk. ( 2001 ). Common Text Book;Strategi Pembelajaran Matematika Kontemporer; untuk Mahasiswa, Guru, dan calon Guru Bidang Studi Matematika. Bandung: Universitas Pendidikan Indonesia.

Buchori., A. ( 2011 ). Media Pembelajaran Microsoft Excel Berbasis Multimedia di SMAN 1 Ngemplak. http://eprints.uny.ac.id/

Darhim, dkk. ( 1996 ). Materi Pokok; Pendidikan Matematika 2; PPDG2332/ 4 SKS; Buku I, Modul 1-7. Jakarta: Universitas Depdikbud, Universitas Terbuka. Bandung: Universitas Pendidikan Indonesia. 
Gunanto dan Adhalia., D. ( 2016 ). Matematika untuk SD/ MI Kelas IV; Kurikulum 2013 yang Disempurnakan. Jakarta: PT. Gelora Aksara Pratama.

Ikranegara., Y. ( 2006 ). Panduan Praktis menguasai Microsoft Office Excel 2003. Bandung: Greisinda Press.

Kusuma., E. Y. ( 2005 ). Matematika untuk SD. Bandung: Pakar Raya.

Listiani., Choirul.,Ekawati., E., dan Purnomo., J. ( 2018 ). Modul PKB SD Kelas Tinggi; Terintegrasi PPK dan Pengembangan Soal; KK I; Pedagogi: Pemanfaatan TIK dalam pembelajaran di SD. Jakarta: Kemdikbud; Dirjen GTK.

Shamsudin., B. ( 2007 ). Kamus Matematika Bergambar untuk Sekolah Dasar. Jakarta: PT. Gramedia Widiasarana Indonesia.

Suratni., K. ( 2012). Pemanfaatan Ms -Excel sebagai Media Pembelajaran Matematika (Grafik Fungsi).

https://mahasuryaa.wordpress.com/2012/02/26/pemanfaatanms excel- sebagai-media-pembelajaran-matematika/

Tualeka., Z., dkk. ( 2007 ). Ayo Bermain Matematika dengan Komputer. Jakarta: PT Mitra Aksara Panaitan.

Idris, S., \& Tabrani ZA. (2017). Realitas Konsep Pendidikan Humanisme dalam Konteks Pendidikan Islam. Jurnal Edukasi: Jurnal Bimbingan Konseling, 3(1), 96-113. https:// doi.org/10.22373/je.v3i1.1420

Siswanto, R., Sugiono, S., \& Prasojo, L. (2018). The Development of Management Model Program of Vocational School Teacher Partnership with Business World and Industry Word (DUDI). Jurnal Ilmiah Peuradeun, 6(3), 365-384. doi:10.26811/peuradeun.v6i3.322

Siahaan, A. (2017). Teachers' Reading Culture in Madrasah Tsanawiyah Environment of the Target Grant Program of School and Quality Component Assistance. Jurnal Ilmiah Peuradeun, 5(3), 415-430. doi:10.26811/peuradeun.v5i3.169

Pamela, C., Villalobosl, L., \& Peralta, N. (2017). Difference Cultural Structure and Behavior Students in Learning Process. Jurnal Ilmiah Peuradeun, 5(1), 15-24. doi:10.26811/peuradeun.v5i1.115 